\title{
PHYTOCHEMICAL PROFILING AND EFFICACY EVALUATION OF ANTIBACTERIAL POTENTIAL OF MYRISTICA FRAGRANS SEED EXTRACTS AGAINST SELECTED MICROORGANISMS
}

\author{
RAJESH SINGH TOMAR, VIKAS SHRIVASTAVA* \\ Amity Institute of Biotechnology, Amity University, Madhya Pradesh, India. Email: vshrivastava@gwa.amity.edu
}

Received: 29 July 2016, Revised and Accepted: 10 August 2016

\section{ABSTRACT}

Objective: Traditional plants have been proved as a novel source for health-care remedies. The plants are the rich source of bioactive compounds which can be useful for health-care purpose. Emergence of resistance among pathogenic bacteria against available antibiotics is a common phenomenon. Hence, the plant-based bioactive molecule may be an alternative for the development of new formulation. The use of natural bioactive molecules as a parental compound for the development of new formulation may be safer with fewer side effects as compared to synthetic chemical compounds. Myristica fragrans seed is widely used in routine life from ancient time for health care. Traditionally, it is being used in for stomach related complications. Hence, the current study pertained to the phytochemical profiling of $M$. fragrans seed and its efficacy evaluation against some clinically significant bacterial species.

Methods: In this study, ethanol and acetone extract of $M$. fragrans seed (Jaiphal) were prepared via using soxhlet apparatus. Extract was qualitatively analyzed to check the phytochemical composition. Then antibacterial efficacy of prepared extracts were analyzed by agar well diffusion assay against Escherichia coli, Bacillus subtilis, Bacillus megaterium, and Proteus mirabilis.

Results: The result of phytochemical profiling shows the presence of tannin, terpenoids, alkaloids, indole, and phenol. Moreover, M. fragrans seed extract exhibiting significant antibacterial activity against selected micro-organisms.

Conclusion: Finding of the study concludes that $M$. fragrans seed (jiphal) possesses the antimicrobial capabilities against infections and/or diseases caused by chosen micro-organisms and seems to be useful in the discovery of novel antibiotic drugs.

Keywords: Myristica fragrans (Jaiphal), Escherichia coli, Bacillus subtilis, Bacillus Megaterium, Proteus mirabilis, Antibacterial activity.

(C) 2016 The Authors. Published by Innovare Academic Sciences Pvt Ltd. This is an open access article under the CC BY license (http://creativecommons. org/licenses/by/4. 0/) DOI: http://dx.doi.org/10.22159/ajpcr.2016.v9i6.14287

\section{INTRODUCTION}

India has a wide diversity of spices and aromatic plants. Moreover, India has been considered as a chief harvester of spices and therapeutic plants in the world. Spices are strong scented substances obtained from dried seeds, fruits, roots, bark, or leaves of different plants. They are used as flavoring agent in food and to enhance the color outlook of several dishes. Spices carry the variety of active compounds which is used traditionally since a long time. The previous studies have indicated about the medicinal potential of different spices such as clove [1], Cinnamomum zeylanicum, Cinnamomum cassia [2], Asafoetida [3], Dagadphool, black pepper [4], fennel [5], and Trachyspermum ammi [6]. It is reported that consumption of $80-200 \mathrm{mg} /$ day of curcumin (bioactive component of turmeric) and $50 \mathrm{~g} / 7$ days of garlic is a routine process in an adult of India [7]. These data suggest a realistic possibility to achieve therapeutic doses of the active ingredients in spices by dietary consumption alone. Effort has been made in India to illustrate the active ingredients of herbal compounds and to demonstrate the benefits of herbal medicines/formulations in a wide variety of applications such as antioxidant, antibacterial, anticancer, anti-diabetic, and anti-inflammatory properties [8].

Myristica fragans is a very important spice. M. fragans belongs to Myristicaceae family. It usually produces two spices, i.e. nutmeg and mace. Nutmeg is the seed inside the fruits. It is commonly known as Jaiphal in India. Seeds are ovoid and red-brownish. The flowering in plants starts after 8-9 years and continue to approximately 70 years. Tropical regions such as Indonesia and Sri Lanka are their main cultivators area [9].

Nutmeg is reported to have great pharmacological activity. Oil of nutmeg has already being used for medicinal purposes from ancient time. It is basically used in the form of spice so as to enhance the taste of several dishes such as tea and milk and alcohols. Traditionally, the nutmeg is used as stomach pain relief, stimulant, carminative along with all this they also possesses antipapillomagenic, anticarcinogenic [10], and antiinflammatory activities [11]. Studies have shown that nutmeg has potent antidiarrheal activity [12]. Still the antimicrobial potential of nutmeg may be explored further, so this study is planned to explore the phytochemical composition and antimicrobial potential of $M$. fragans seed extracts.

\section{METHODS}

Collection of sample

The $M$. fragrans seed (Jaiphal) was obtained from local market.

Solvents used

1. Acetone

2. Ethanol (70\%)

3. Dimethyl sulfoxide (DMSO) (negative control).

Micro-organisms used

1. Escherichia coli

2. Bacillus subtilis

3. Bacillus megaterium

4. Proteus mirabilis.

Above microbes were obtained from microbial type culture Collection, Chandigarh.

\section{Preparation of extracts}

The seed of $M$. fragrans (nutmeg) is broken into small pieces under sterile conditions, and $10 \mathrm{~g}$ of nutmeg powder was dissolved with $100 \mathrm{ml}$ of $70 \%$ ethanol, and pure acetone for extraction of the active agent. Extraction was done by soxhlet apparatus. Then, mixtures were 
filtered, followed by preparing stock solution and then stored at low temperature $\left(4^{\circ} \mathrm{C}\right)$.

\section{Screening of phytochemicals}

The extracts of nutmeg were screened for the presence of phytochemical constituents.

The methods were followed:

\section{Test for Tannins}

$2 \mathrm{ml}$ of leaf extract was mixed with few drops of $5 \%$ ferric chloride, the occurrence of brown color indicate the presence of tannins.

\section{Test of Terpenoids}

Take $5 \mathrm{ml}$ of aqueous extract add $2 \mathrm{ml}$ chloroform followed by addition of $3 \mathrm{ml}$ concentration sulfuric acid, observe the reddish brown interface for the presence of terpenoids.

\section{Test for Alkaloids}

Take $1 \mathrm{ml}$ of aqueous extract in test tube and add 2-3 drops of Wagner's reagent it gives orange precipitation.

\section{Test for Indole}

To $2 \mathrm{ml}$ of extract of the plant with Ehrlich reagent. Red or purple color indicates the presence of indole.

\section{Test for Phenols}

To $1 \mathrm{ml}$ of extract, $2 \mathrm{ml}$ of distilled water and a few drops of $10 \%$ of aqueous $\mathrm{Fecl}_{3}$ were added. Formation of blue or green color showed the presence of phenol.

\section{Screening for antimicrobial activities}

The antibacterial activity studies were carried out by well diffusion method [13]. The sterile M.H agar plates were prepared. Wells were then bored into the plates using sterile cork borer of $6 \mathrm{~mm}$ in diameter The bacterial test organisms such as E. coli, B. subtilis, B. megaterium, and Proteus mirabilis were spread over the agar plates using separate sterile spreader. Then $50 \mu \mathrm{l}$ extracts (concentration $200 \mathrm{mg} / \mathrm{ml}$ ) in DMSO were placed on the wells of different plates. All bacterial plates were incubated at $37^{\circ} \mathrm{C}$ for $24 \mathrm{hrs}$. The diameter of the minimum zone was measured in $\mathrm{mm}$.

\section{RESULT AND DISCUSSION}

In this study, M. fragrans seed (Jiphal) was used for phytochemica profiling and antimicrobial activity. The phytochemical active compounds of extract were qualitatively analyzed separately. In this process, tannin, terpenoid, alkaloids, indole and phenol showed significant results. Then, the antimicrobial potential of different extracts was analyzed by well diffusion methods, which shows the diversified results.

Table 1 shows the result of phytochemical analysis of $M$. fragrans seed extract. In these tannins, terpenoid, alkaloids, indole, and phenol analysis were done. All the phytochemicals were present in the extract.

The previous studies indicate that the medicinal and healing properties of herbs are closely related to their chemical components which are classified into some major groups such as alkaloids, acids, essential oils, steroids, saponins, and tannins and getting these chemicals out into the herbal remedy depend on the solubility of these compounds in various solvents $[14,15]$. The results of our study also showed the presence of respective phytochemicals, which also support the above-mentioned studies.

\section{Antimicrobial activity}

Fig. 1 shows the results of antimicrobial activity of different extracts against chosen microorganisms. The results indicate highest activity
Table 1: The result of phytochemical analysis of Myristica fragrans seed extract

\begin{tabular}{llll}
\hline S.N & Phytochemicals & $\begin{array}{l}\mathbf{7 0 \%} \text { ethanolic extract } \\
\text { of } \boldsymbol{M} \text {. fragrans seed }\end{array}$ & $\begin{array}{l}\text { Acetone extract of } \\
\text { M. fragrans seed }\end{array}$ \\
\hline 1 & Tannin & + & + \\
2 & Terpenoids & + & + \\
3 & Alkaloids & + & + \\
4 & Indole & + & + \\
5 & Phenol & + & + \\
\hline \multicolumn{3}{l}{ M. fragrans: Myristica fragrans }
\end{tabular}

Result showing antibacterial activity of Myristica fragrans seed

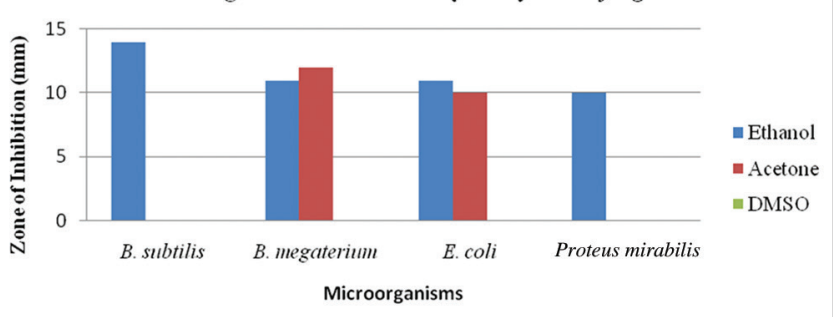

Fig. 1: The antibiotic sensitivity zone of the ethanolic and acetone extract of nutmeg as compared with dimethyl sulfoxide

in ethanollic extract of nutmeg (14 mm) against Bacillus subtilis, in addition to that ethenolic and methenolic extracts of seed showed the significant activity against Bacillus megaterium $(11 \mathrm{~mm}$ and $12 \mathrm{~mm}$, respectively) and E. coli (10 $\mathrm{mm}$ and $11 \mathrm{~mm}$, respectively), whereas P. mirabilis shows moderate sensitivity $(10 \mathrm{~mm})$ toward ethanolic extract of seed of M. fragrans (Jiphal). DMSO was considered as negative control.

In the previous study, Kadhim et al. have shown the antibacterial activity of nutmeg against some Gram-positive and Gram-negative species [16] whereas in another study Takikawa et al. have shown the antibacterial activity against non-pathogenic E. coli. [17], In addition to that Shafiei et al. have observed the antimicrobial activity of nutmeg against oral pathogens [18]. Hence, the results of our study also strengthen the previous studies the antimicrobial potential of the extracts may be due to the presence rich phytochemical compositions.

\section{CONCLUSION}

In this study, the antimicrobial activity of $M$. fragrans (jiphal) extracts was tested against chosen micro-organism. The results indicate the wide range of antibacterial sensitivity. This may be due to the extraction of bioactive compounds from $M$. fragrans using acetone and ethanol as solvent. The results obtained from the study clearly suggest that the chosen spice is expected to give most diverse outcomes in the area of new formulation development. However, the study needs further exploration to determine the exact mechanism behind the antimicrobial activity of the chosen extract, which may enhance the pharmacological application of the selected compound. On the basis of the present finding, $M$. fragrans (jiphal) possess the capabilities of being a good candidate in the search for a natural antimicrobial agent against infections and/or diseases caused by E. coli, B. subtilis, B. megaterium, Proteus mirabilis. Further research is needed to understand the role of active principle component in the extracts, and their potent role could possibly be exploited for pharmaceutical use.

\section{ACKNOWLEDGMENT}

Authors wish to express our sincere acknowledgement to Dr. Ashok Kumar Chauhan, President, RBEF parent organization of Amity University Madhya Pradesh (AUMP), Dr. Aseem Chauhan, Additional President, RBEF and chairman of AUMP, Gwalior, Lt. Gen. V.K. Sharma, AVSM (Retd.), Vice Chancellor of AUMP, Gwalior for providing necessary 
facilities, their valuable support and encouragement throughout the work.

\section{REFERENCES}

1. Ayoola GA, Lawore FM, Adelowotan T, Aibinu IE, Adenipekun E, Coker HA, et al. Chemical analysis and antimicrobial activity of the essential oil of Syzigium aromaticum (clove). Afr J Microbiol Res 2008;2:162-6.

2. Nimje PD, Garg H, Gupta A, Srivastava N, Katiyar M, Ramalingam C. Comparison of antimicrobial activity of Cinnamomum zeylanicum and Cinnamomum cassia on food spoilage bacteria and water borne bacteria. Der Pharm Lett 2013;5(1) 53-9.

3. Patil SD, Shinde S, Kandpile P, Jain AS. Evaluation of antimicrobial activity of asafoetida. Int J Pharm Sci Res 2014;6(2):722-7.

4. Shete HG, Chitanand MP. Antimicrobial activity of some commonly used Indian Spices. Int J Curr Microbiol Appl Sci 2014;3(8):765-70.

5. Dua A, Garg G, Mahajan R. Polyphenols, flavonoids and antimicrobial properties of methanolic extract of fennel (Foeniculum vulgare Miller). Eur J Exp Biol 2013;3(4):203-8.

6. Shelef LA. Antimicrobial effects of spices. J Food Saf 1983;6(1):29-44

7. Chattopadhyay I, Biswas K, Bandyopadhyay U, Banerjee RK. Turmeric and curcumin: Biological actions and medicinal applications. Curr Sci 2004;87(1):44-53.

8. Choi EM, Hwang JK. Antiinflammatory, analgesic and antioxidant activities of the fruit of Foeniculum vulgare. Fitoterapia 2004;75:557-65.

9. Encyclopedia Britannica. Available from: https://www.britannica.com/ topic/nutmeg

10. Hussein G, Miyashiro H, Nakamura N, Hattori M, Kakiuchi N, Shimotohno K. Inhibitory effects of Sudanese medicinal plant extracts on hepatitis C virus (HCV) protease. Phytother Res 2000;14(7):510-6.

11. Ahmadiani A, Javan M, Semnanian S, Barat E, Kamalinejad M. Antiinflammatory and antipyretic effects of Trigonella foenum-graecum leaves extract in the rat. J Ethnopharmacol 2001;75(2-3):283-6.

12. Grover JK, Yadav S, Vats V. Medicinal plants of India with anti-diabetic potential. J Ethnopharmacol 2002;81(1):81-100.

13. Irobi ON, Moo-Young M, Anderson WA, Daramola SO. Antimicrobia activity of the bark of Bridelia fermginea (Euphorbiaceae). Int J Pharmacogn 1994;34:87-90.

14. Cowan MM. Plant products as antimicrobial agents. Clin Microbiol Rev 1999;12(4):564-82

15. Darout IA, Christy AA, Skaug N, Egeberg PK. Identification and quantification of some potentially antimicrobial anionic components in miswak extract. Indian J Pharmacol 2000;32(1):11-4.

16. Ibrahim KM, Naem RK, Abd-Sahib AS. Antibacterial activity of nutmeg (Myristica fragrans) seed extracts against some pathogenic bacteria. J Al-Nahrain Univ 2013;16(2):188-92.

17. Takikawa A, Abe K, Yamamoto M, Ishimaru S, Yasui M, Okubo Y, et al. Antimicrobial activity of nutmeg against Escherichia coli O157. J Biosci Bioeng 2002;94(4):315-20.

18. Shafiei Z, Shuhairi NN, Yap NM, Sibungkil CA, Latip J. Antibacterial activity of Myristica fragrans against oral pathogens. Evid Based Complement Alternat Med 2012;2012:7. 